\title{
CHARACTERIZATION OF RICE AND RICE STARCH OF DIFFERENT CULTIVARS
}

\author{
BY \\ LAKSHITHA KANAGESWARAN
}

A THESIS SUBMITTED TO THE DEPARTMENT OF FOOD SCIENCE AND TECHNOLOGY, FACULTY OF APPLIED SCIENCES UNIVERSITY OF SRI JAYEWARDENEPURA FOR THE DEGREE OF MASTER OF FOOD SCIENCE AND TECHNOLOGY 


\section{DECLARATION}

"I declare that this thesis submitted by me for MSc. degree in Food Science and Technology at the University of Sri Jayewardenepura. This thesis contains no material that has been submitted previously, in whole or in part, for the award of any other academic degree or diploma. Except where otherwise indicated, this thesis is my own work"

Ki Lakthitha

K. Lakshitha

(MSc Student)

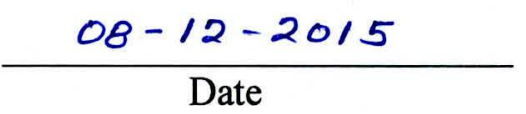




\section{DECLARATION}

"We certify that the above statement made by the candidate is true and that thesis is suitable for submission to the University for the purpose of evaluation"

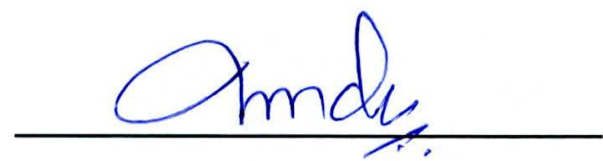

Dr. (Mrs.) Indira Wickramasinghe Senior Lecturer,

Department of Food Science \& Technology, Faculty of Applied Sciences,

University of Sri Jayewardenepura, Sri Lanka.

\section{S. Balamman}

Dr. S. Balakumar, Senior Lecturer, Department f Biochemistry, Faculty of Medicine, University of Jaffna, Sri Lanka. 


\section{DEDICATION}

I dedicate this to my family, supervisors, friends and fellow members without whom it was almost impossible for me to complete my thesis work. 


\section{TABLE OF CONTENTS}

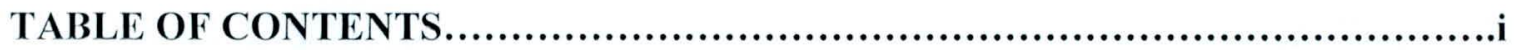

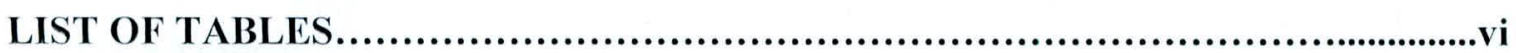

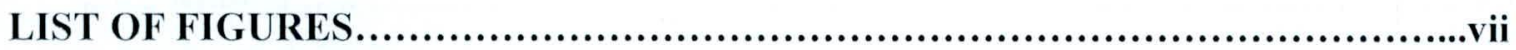

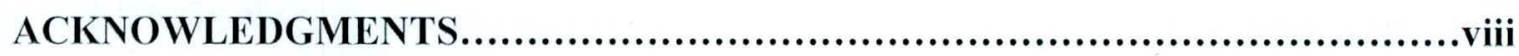

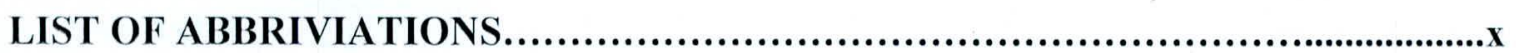

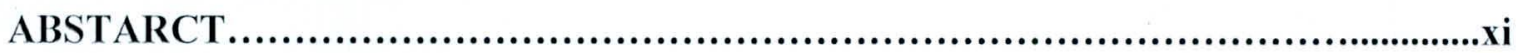

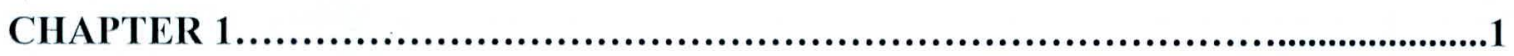

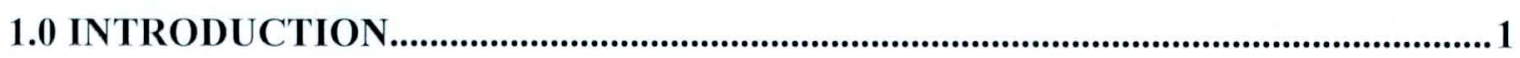

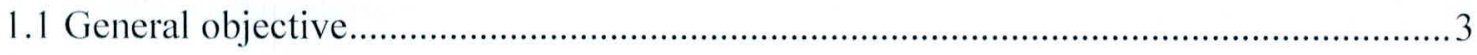

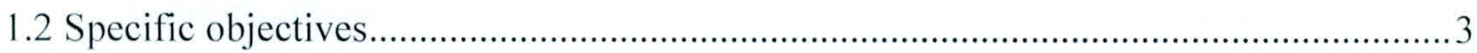

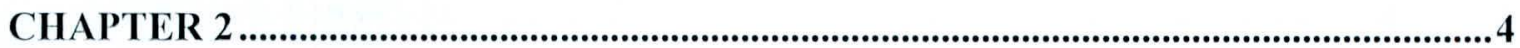

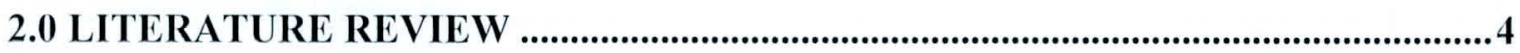

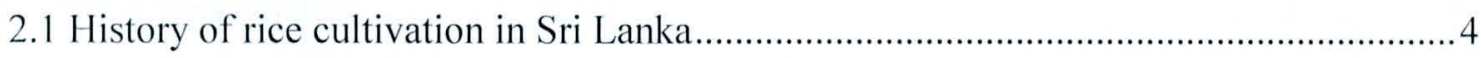

2.1.1 The two main cultivation seasons....................................................................... 5

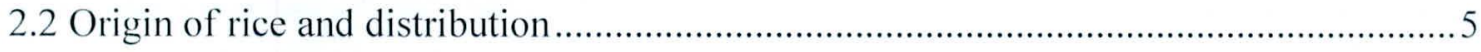

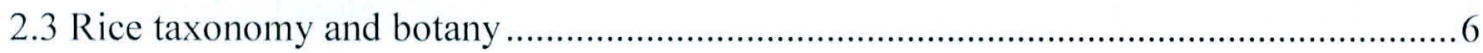

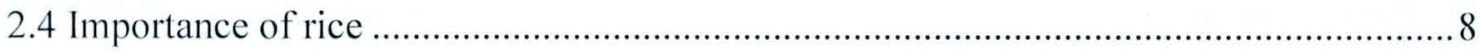

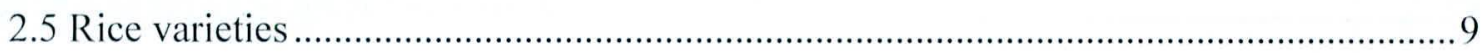

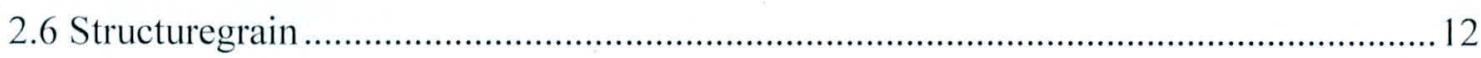

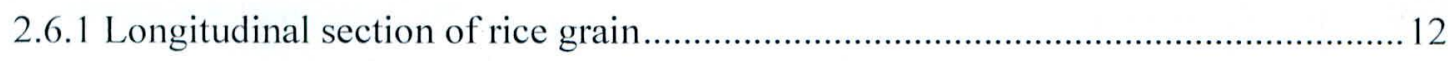

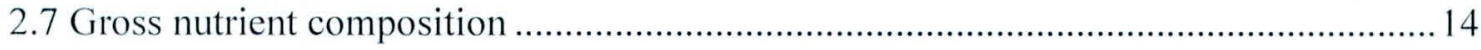

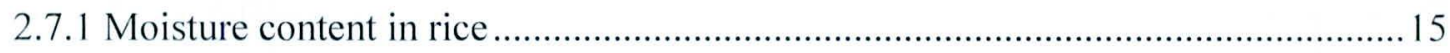

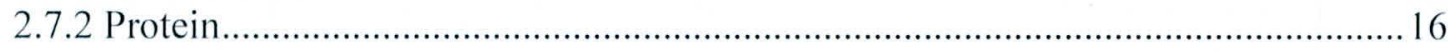

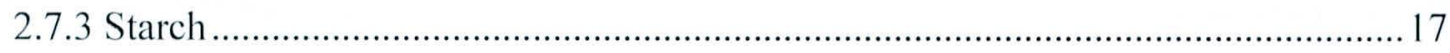

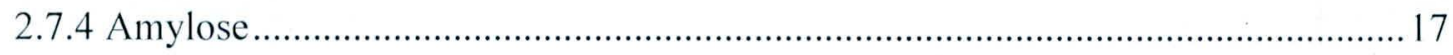

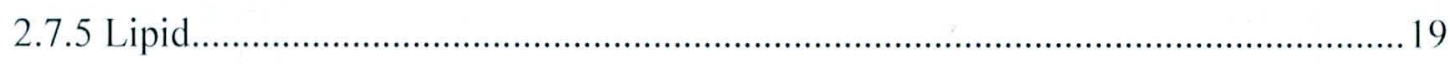

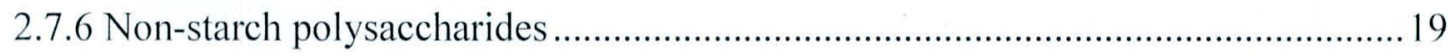

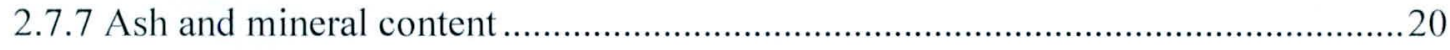

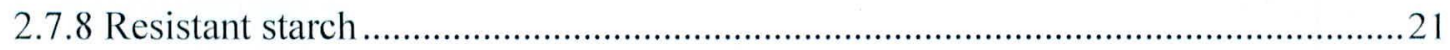

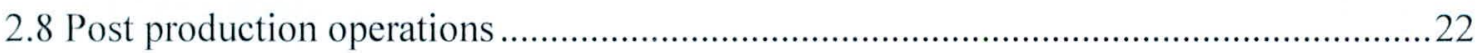

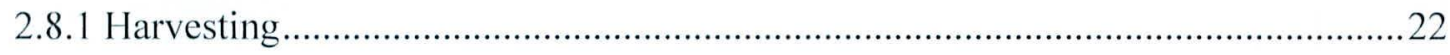

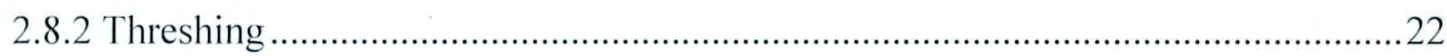




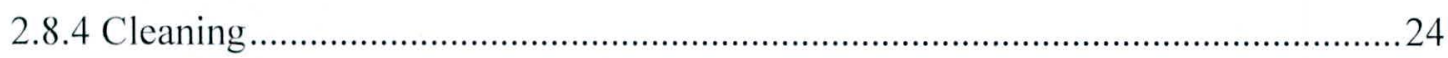

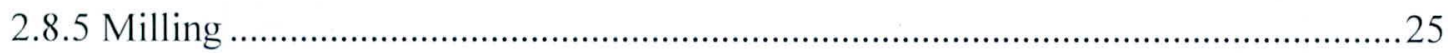

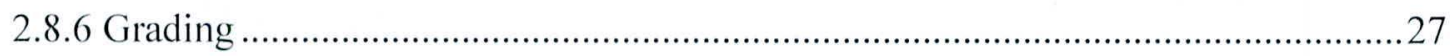

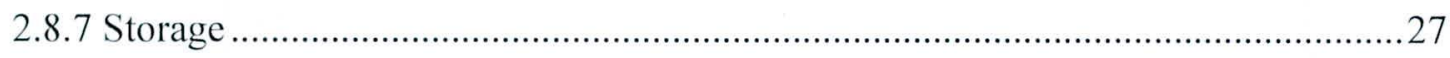

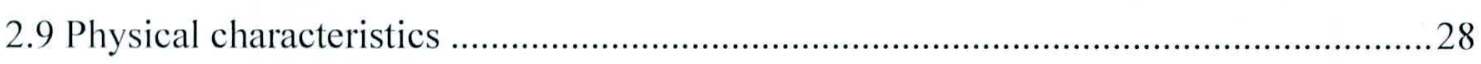

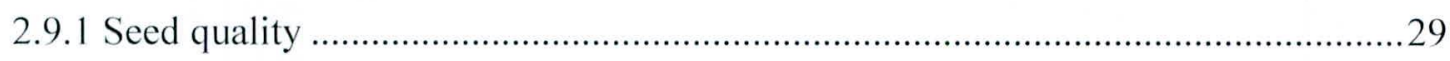

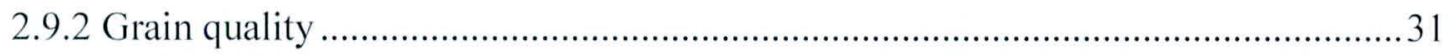

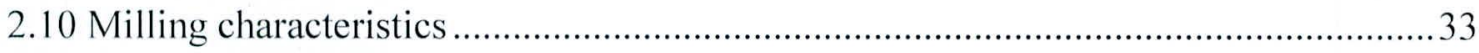

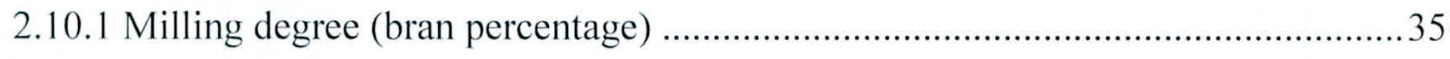

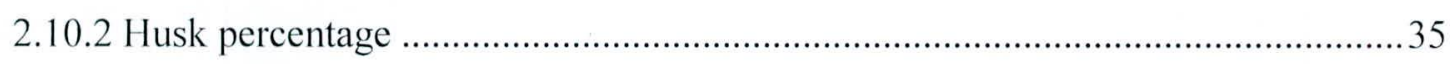

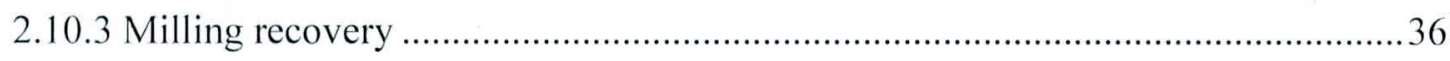

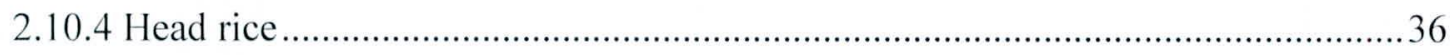

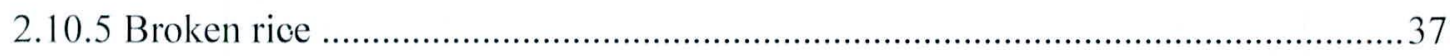

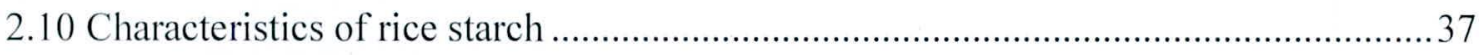

2.10.1 Water binding capacity, swelling power,and solubility pattern ......................... 37

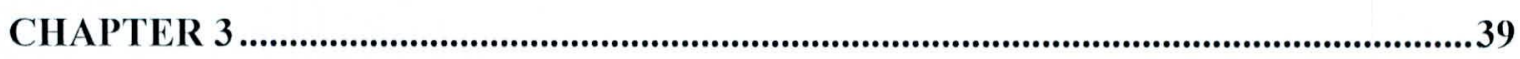

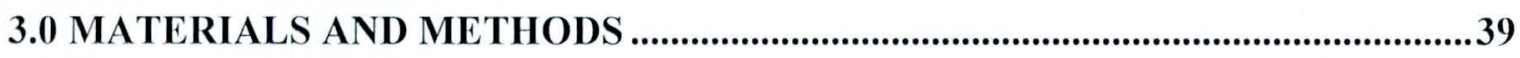

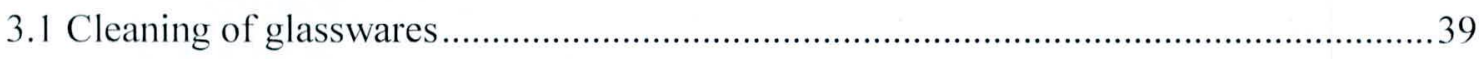

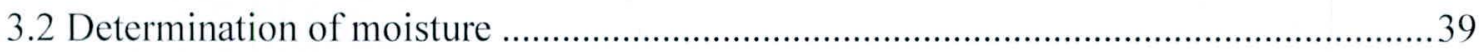

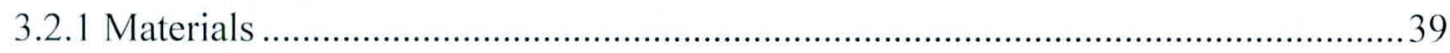

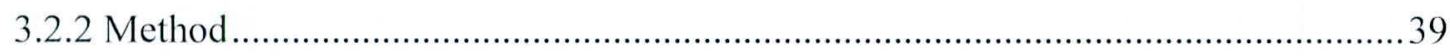

3.3 Standard curve for glucose by 3,5-dinitrosalicylic acid (DNS) method .......................40

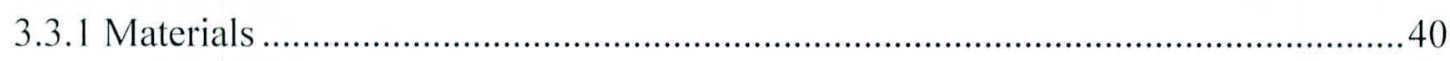

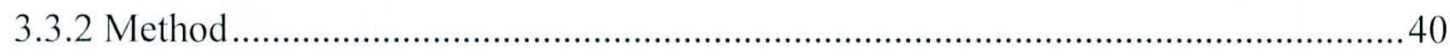

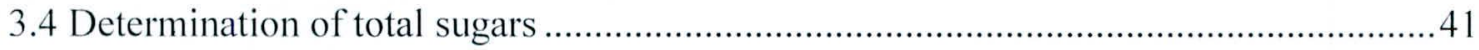

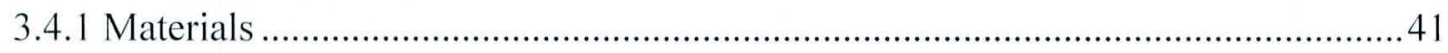

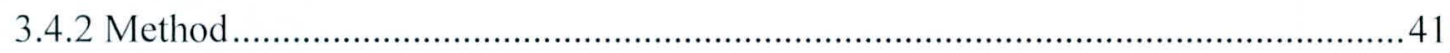

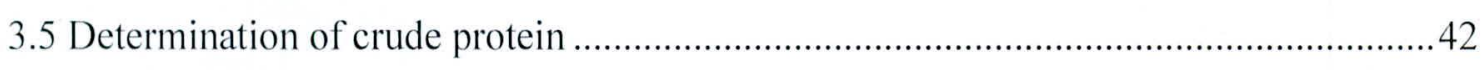

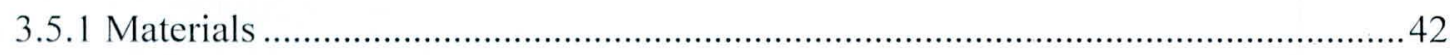

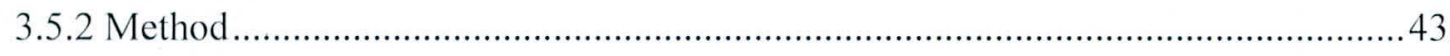

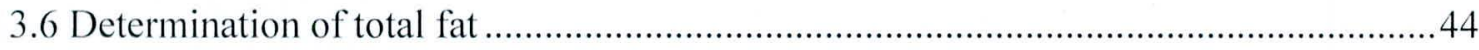




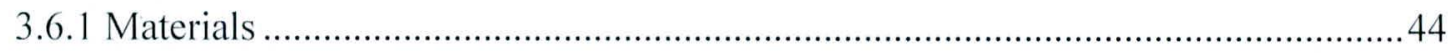

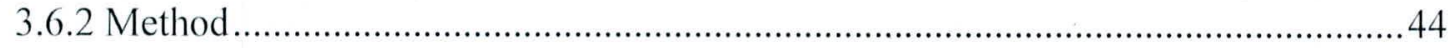

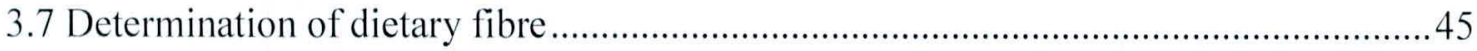

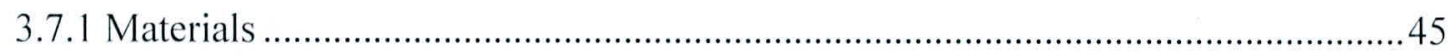

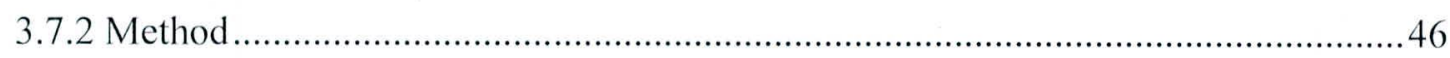

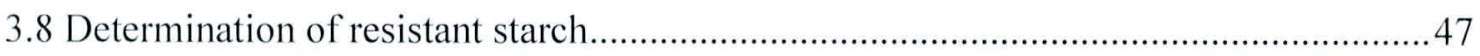

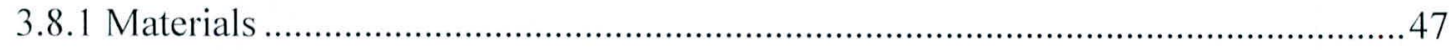

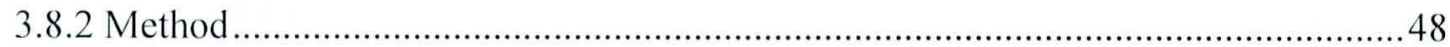

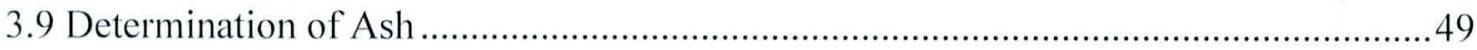

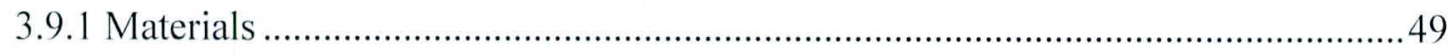

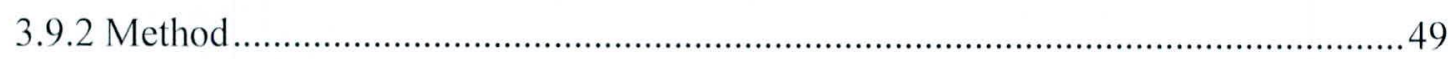

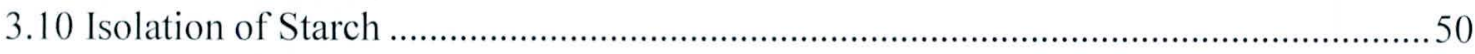

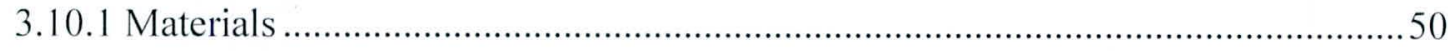

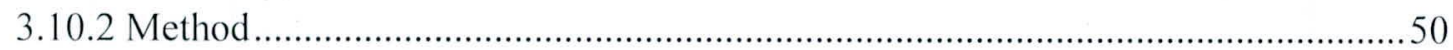

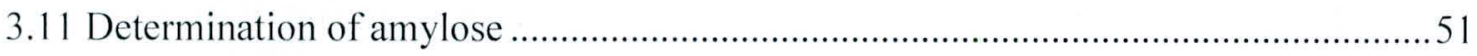

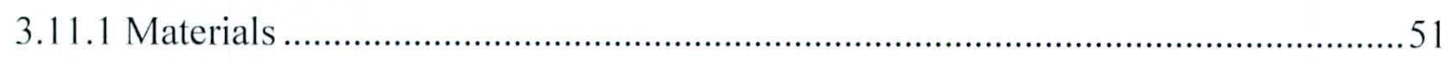

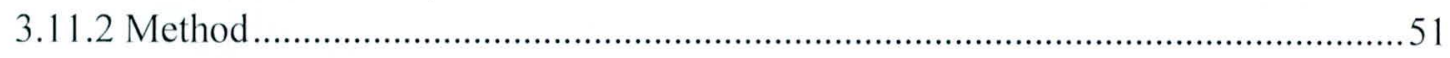

3.12 Determination of swelling power and solubility …..................................................52

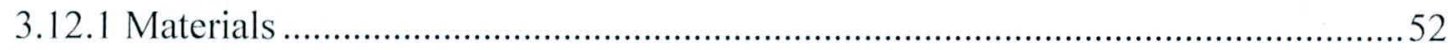

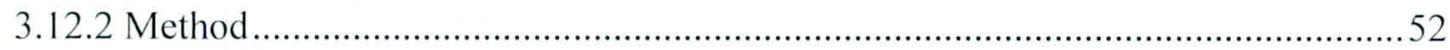

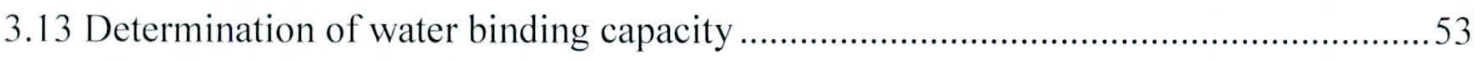

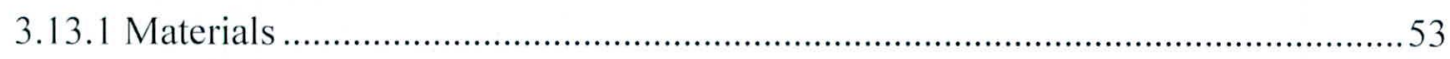

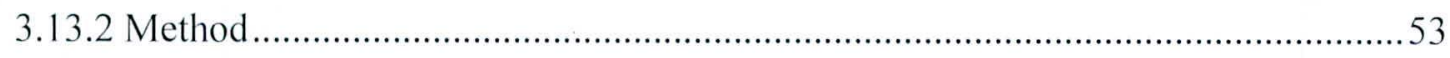

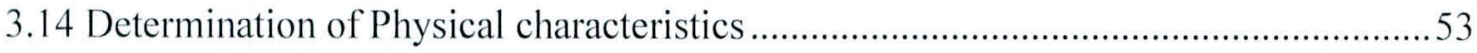

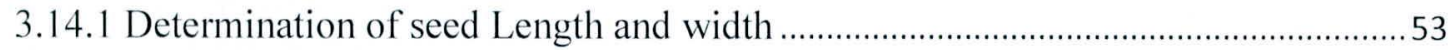

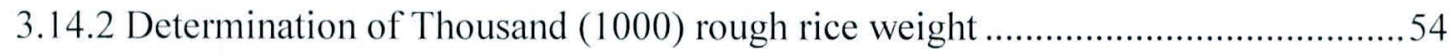

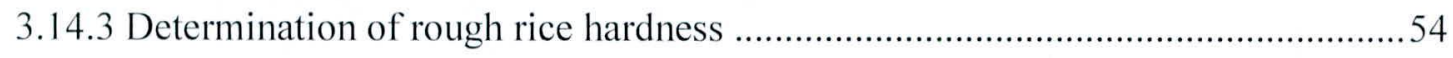

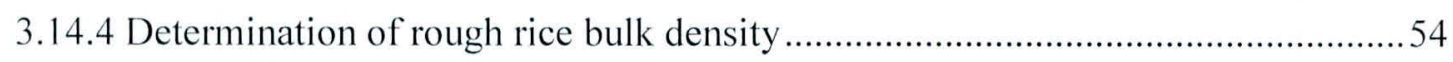

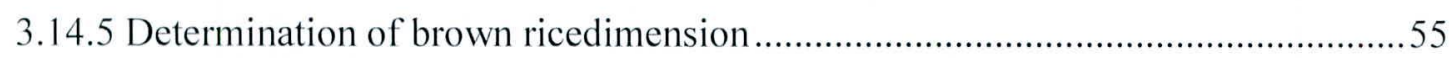

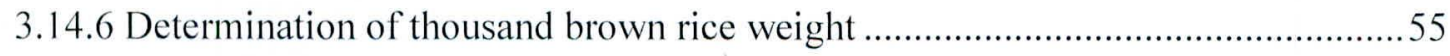

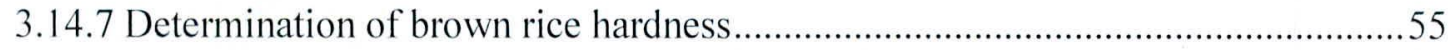

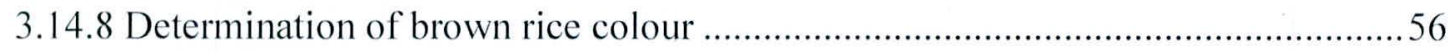

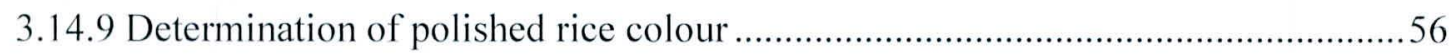




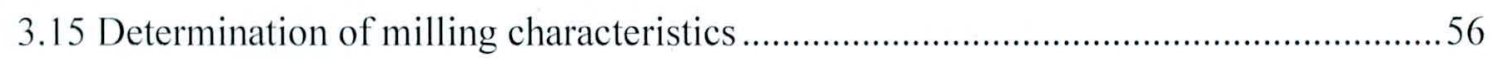

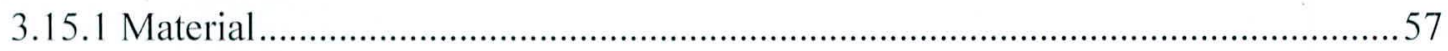

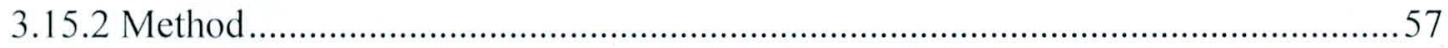

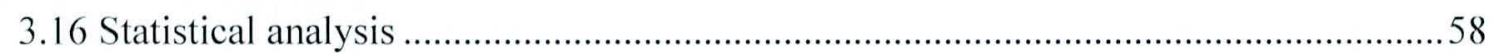

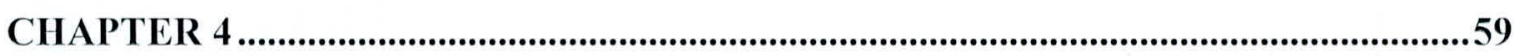

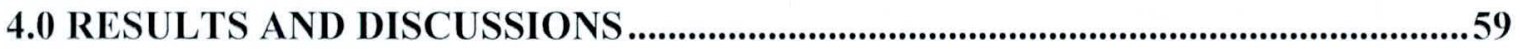

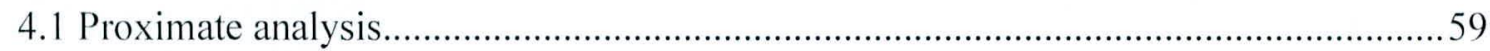

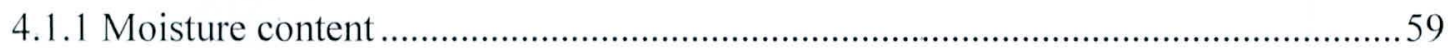

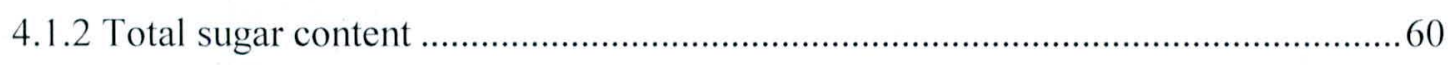

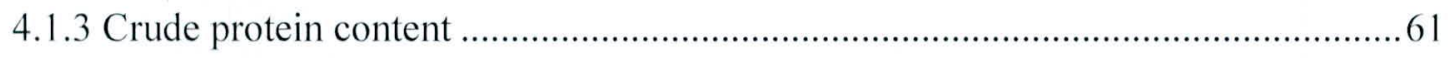

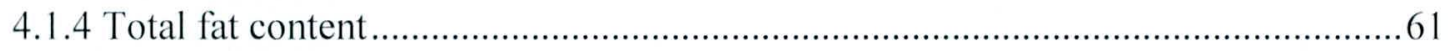

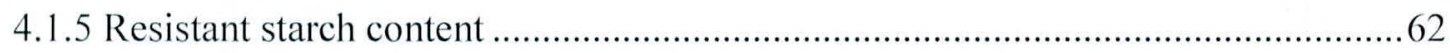

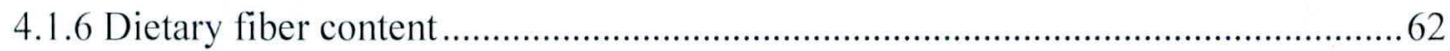

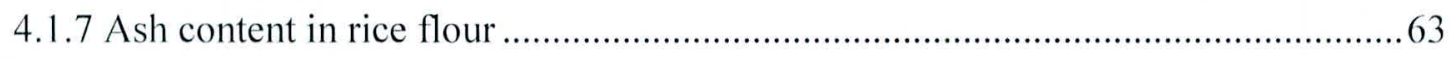

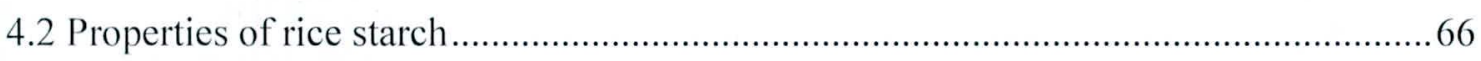

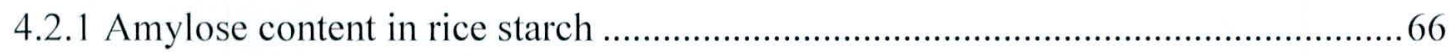

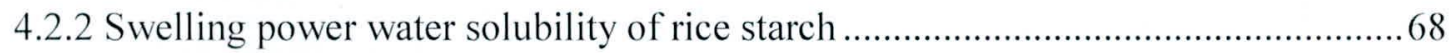

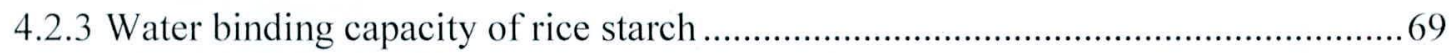

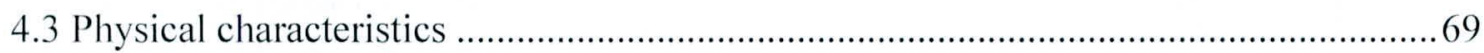

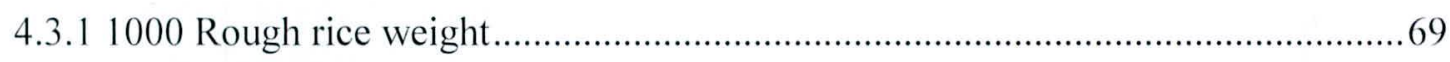

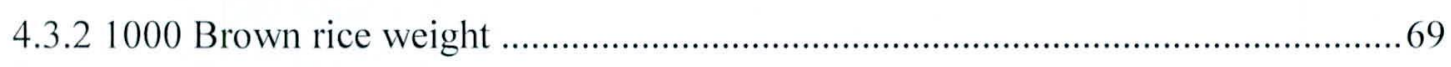

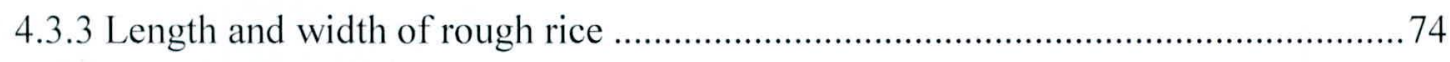

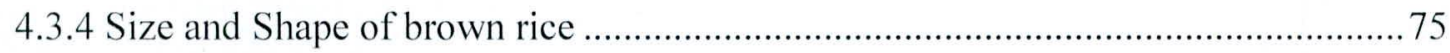

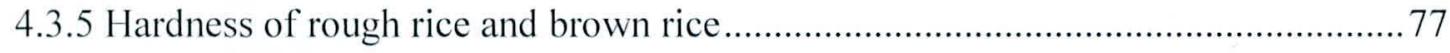

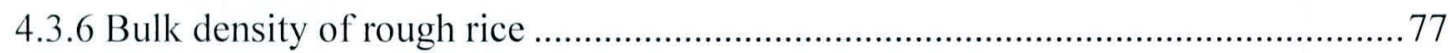

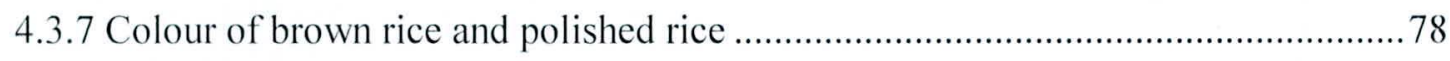

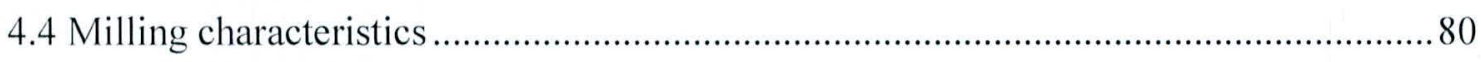

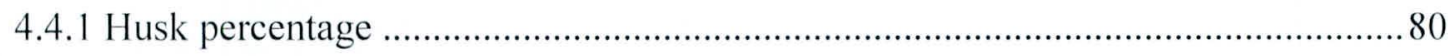

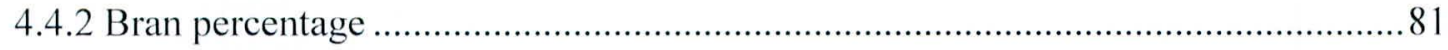

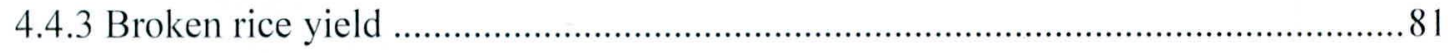

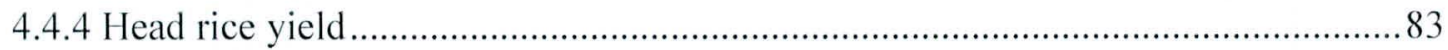

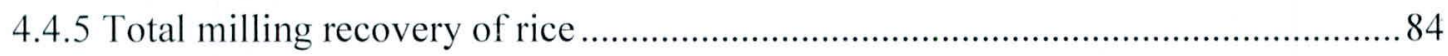




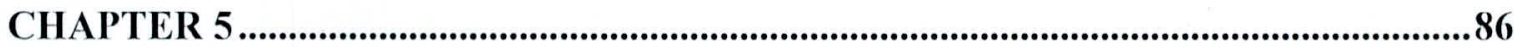

5.0. CONCLUSIONS AND RECOMMENDATIONS..........................................................86

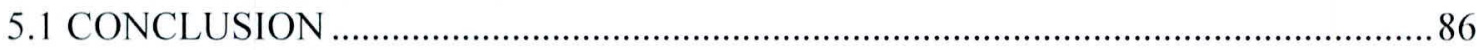

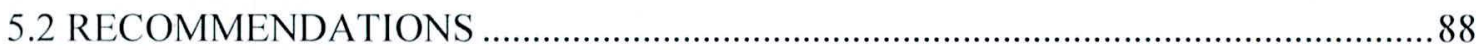

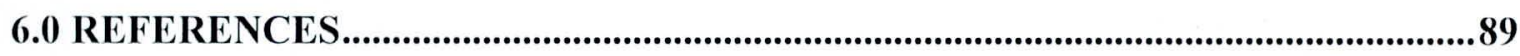

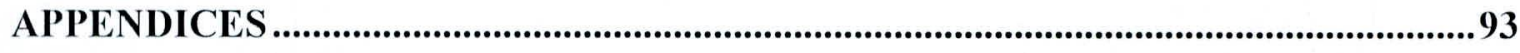

Appendix 1: Ten rice varietal Analysis of Variance (ANOVA) with eight proximate

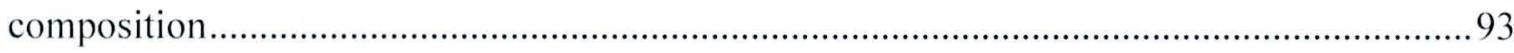

Appendix 2: Ten rice varietal Analysis of Variance (ANOVA) with properties of Rice starch .95

Appendix 3: Eight rice varietal Analysis of Variance (ANOVA) with physical characteristics

Appendix 4: Eight rice varietal Analysis of Variance (ANOVA) with milling characteristics 


\section{LIST OF TABLES}

Table 2.1: Proximate composition of rough rice and its milling fractions at $14 \% \ldots . .15$

Table 2.2:Vitamin and mineral content of rough rice and its milling fractions at.......21

Table 2.3:Quality of paddy threshed by tractors and mechanical threshers ...............23

Table 2.4: The threshing efficiency in mechanical threshing is significantly higher ..23

Table 2.5: Classification of rough rice based on length and width............................... 31

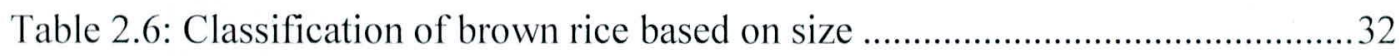

Table 2.7: Classification of brown rice based on shape ........................................... 33

Table 4.1: Proximate Composition parameters means for ten rice varieties ...............64

Table 4.2: Properties of rice starch of each varieties ................................................67

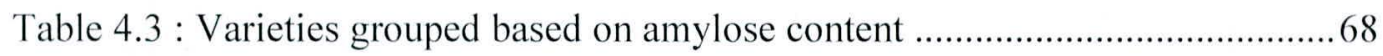

Table 4.4 : Physical characteristics of rough rice .................................................. 71

Table 4.5 : Physical characteristics of brown rice ................................................. 72

Table 4.6: Varieties grouped based on the thousand rough rice weight ...................73

Table 4.7 : Varieties grouped based on the thousand brown rice weight ..................73

Table 4.8: Varieties grouped based on the length of rough grain............................ 74

Table 4.9: Varieties grouped based on the shape of rough rice .................................75

Table 4.10: Varieties grouped based on the size brown rice ..................................76

Table 4.11: Varieties grouped based on the shape of brown rice ……….................. 76

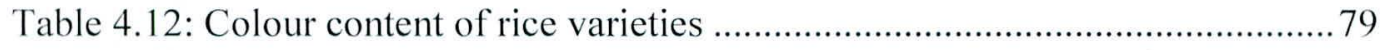

Table 4.13: Milling characteristics of rice varieties ............................................... 82 


\section{LIST OF FIGURES}

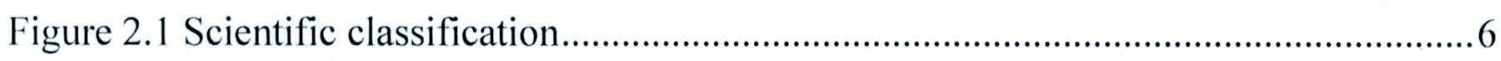

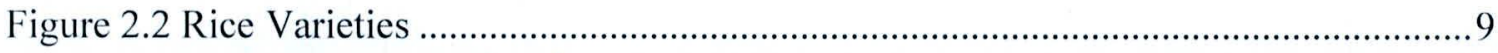

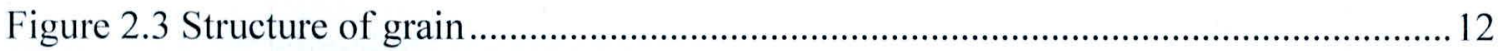

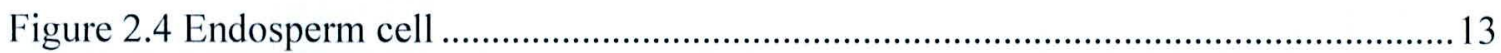

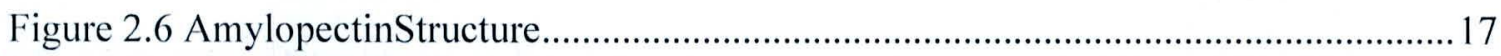

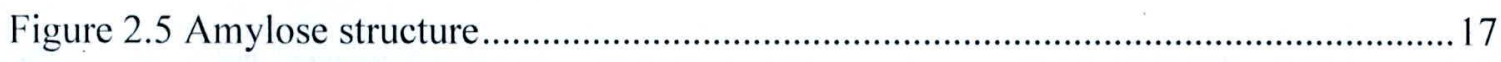

Figure 4.1 : Plot of absorbance at 550nm against glucose concentration..............................60

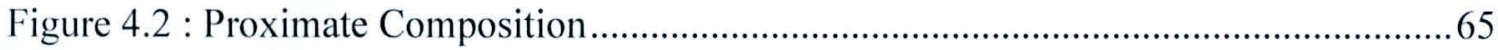

Figure 4.3: Plot of absorbance at $620 \mathrm{~nm}$ against concentration of amylose $(\mathrm{mg} / \mathrm{ml})$ for .....67

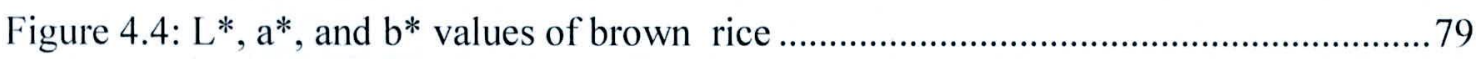

Figure 4.5: $\mathrm{L}^{*}$ value between brown rice and polished rice .......................................... 80

Figure 4.6: Relationship between head rice (\%) and broken rice $(\%)$..............................8 84

Figure 4.7: Relationship between head rice percentage and total yield..............................85 
I wish to express my sincere thanks to Dr. Champathi Gunatileke who greatly assisted me to do the research at Institute of Post Harvest Technology, Anuradhapura.

I would also like to show my gratitude Mrs. S. Sritharan, Mrs. K. Niththiyanantharajah and Mr. K. Thayananthan, Technical staff, Department of Biochemistry.

I take this opportunity to express my gratitude to staffs of Faculty of Agriculture, University of Jaffna, Palmyrah Research Institute, Kaithady, Jaffna and Staffs of IPHT and laboratory technicians.

I would also like to thank to Mr. N. Niththiyanantharajah, Mr. T. Santhiramoorthy, Mr. M. Sutharsan, Mr. V. Jeyabalasundaram, Mr. Balasingham, Mr. P. Mohan and Mr. P. Kirupanantharajah for their assistance and cooperation.

Last but not the least, I would like to thank my family, especially to my parents, my brother and my husband who provided me with unending encouragement and support to complete my tasks. 


\section{LIST OF ABBRIVIATIONS}

FAO Food and Agriculture Organization

ANOVA Analysis of Variance

AOAC Association of Official Analytical Chemists

DMRT Duncan's Multiple Range Test

IRRI International Rice Research Institute

B.C Before Christ

DNS Dinitrosalicylic acid

At Ambalangoda

Bg Bathalagoda

PB Protein Body

CRH Carbonized Rice Husk

RHA Rice Husk Ash

KI Potassium Iodide

$\mathrm{NaOH} \quad$ Sodium Hydroxide

$\mathrm{KOH} \quad$ Potassium hydroxide

CuSO4 Copper Sulphate

K2SO4 Potassium Sulphate

$\mathrm{HCl} \quad$ Hydrochloric acid

DF Dietary Fiber

RS Resistant starch 


\begin{abstract}
\end{abstract}
This study was carried out to find the physical, chemical characteristics of rice and rice starch of traditional and improved rice cultivars namely Motaikarupan, Morungan, Pachachperumal, Suwenthal, Pusparaga, Atakari, BG300, At308, BG406, BG250.The proximate composition for the ten varieties were variable with respective ranges being moisture $13.390 \%$ to $9.460 \%$, total sugar $86.45 \%$ to $79.45 \%$, crude protein $8.15 \%$ to $5.79 \%$, total fat $3.5400 \%$ to $2.2150 \%$, resistant starch $0.69 \%$ to $0.405 \%$, ash $1.6900 \%$ to $0.8950 \%$, Dietary fiber $4.10 \%$ to $2.20 \%$. All these result were found to be significantly different $(\mathrm{P}<0.05)$.The starch properties including amylose content, water solubility, swelling power and water binding capacity were estimated for ten rice varieties, varied from $30.8010 \%$ to $23.2005 \%, 8.4695 \%$ to $4.7900 \%, 12.57 \%$ to $10.2300 \%, 3.1028 \%$ to $2.4400 \%$, respectively $(\mathrm{P}<0.05)$.Analysis of milling quality parameters of the eight rice varieties were showed that there is a significant different $(\mathrm{P}<0.05)$. The husk content $21.0101 \%$ to $18.4601 \%$, bran content $10.5495 \%$ to $6.5575 \%$, total recovery $73.3290 \%$ to $67.8850 \%$, head rice $67.5902 \%$ to $22.9010 \%$, broken rice $67.2780 \%$ to $5.2500 \%$. The physical properties of rough rice and brown rice were analyzed. According to rough rice length the rice varieties were classified into three groups, long (1 variety), medium (5 varieties) and short (2 varieties) and they were further classified based on their width rough rice were classified into two groups as semi spherical (3 varieties), semi long ( 5 varieties). With brown rice length the rice varieties were grouped into two groups as medium (6 varieties) and short (2 varieties) and also grouped in three based on the length to width ratio as slender (2 varieties), medium ( 5 varieties) and bold ( 1 variety). Based on the thousand rough rice weights, the varieties were categories into 7 ranges; below 15 grams (1 variety), 15-18grams (2 varieties), 18 to 21 grams (1 varieties), 21 to 24 grams (1 variety), 24 to 27 (1 variety), 27 to 30 (1 Variety), 33 to 36 (1 variety) and the brown rice were also grouped into 5 according to their thousand grain weight ranges; below 
15 grams (1 variety), 15 to 18 grams (2 varieties), 18 to 21 grams (2 varieties), 21 to 24 (1 variety), 24 to 27 (2 varieties).Bulk density of the rough rice were ranged from $0.6615 \mathrm{~g} / \mathrm{ml}$ to $0.6110 \mathrm{~g} / \mathrm{ml}(\mathrm{P}<0.05)$. The hardness of rough rice and brown rice were stated $112 \mathrm{~N}$ to $51.6 \mathrm{~N}$ and $46.6 \mathrm{~N}$ to $20.4 \mathrm{~N}$ respectively. The color of brown rice stated according to $\mathrm{L}^{*}, \mathrm{a}^{*}$ and $\mathrm{b}^{*}$ values, 62.453 to $44.230(\mathrm{p}<0.05), 9.597$ to $0.640(\mathrm{p}<0.05), 17.927$ to $10.860(\mathrm{p}>0.05)$ respectively and the color of polished rice $L^{*}$ value was ranged from 71.63 to $68.29(p<0.05)$ 